\title{
Input Use Efficiency of Cocoa Farmers in Ondo State, Nigeria
}

\author{
Oluyole, K.A. ${ }^{1 *}$, Usman, J.M. ${ }^{2}$, Oni, O.A. ${ }^{3}$, Oduwole, O.O. ${ }^{1}$ \\ ${ }^{1}$ Economics and Statistics Division, Cocoa Research Institute of Nigeria, Ibadan, Nigeria \\ ${ }^{2}$ Federal College of Forestry, PMB 5087, Jericho, Ibadan, Nigeria \\ ${ }^{3}$ Department of Agricultural Economics, University of Ibadan, Ibadan, Nigeria \\ *Corresponding author: kayodeoluyole@y ahoo.com
}

Received January 11, 2013; Revised January 25, 2013; Accepted February 25, 2013

\begin{abstract}
The study assessed the input use efficiency of cocoa farmers in Nigeria. Simple random sampling technique was used to select 90 cocoa farmers from the state. Structured questionnaire was used to collect information from the respondents. Empirical analysis revealed that cocoa production is profitable with average gross revenue, average gross margin and average net farm income of N722,827, N613,335 and N602,152 respectively. Cost of chemicals, cost of labour, cost of nylon, cost of cutlass and cost of sprayer are the critical cost items in cocoa production. The elasticity of production for cost of chemicals, cost of labour, cost of nylon, cost of cutlass and cost of sprayer were $78.5 \%, 57.1 \%, 28.2 \%, 31.6 \%$ and $42.2 \%$ respectively indicating that it is the cost of fungicide that is most responsive. Maginal Value Product (MVP) for the cost of chemicals, cost of labour, cost of nylon, cost of cutlass and cost of sprayer were greater than their Maginal Factor Cost (MFC) connoting that cocoa farmers were under-utilising these inputs. The study concluded that cocoa farmers were inefficient in resource utilization and recommended that the quantity of these inputs should be increased to achieve efficiency.
\end{abstract}

Keywords: efficiency, cocoa, maginal value product

\section{Introduction}

Cocoa which belongs to the family Steruliacaea and genus Theobroma was discovered in 18th century at the Amazon basin and later spread to other tropical areas of South and Central America, and West Africa [1]. Since the end of the first world war, West Africa has been the highest producer of cocoa. The crop was eventually introduced into Nigeria in 1887 [2]. Nigeria as a developing country as rated the second largest world producer of cocoa in the 1960s [3], and, for a long time, the crop has been generating substantial foreign exchange earnings for the country. However, the production of this mportant cash crop for export has suffered a reduction in the recent years in the country owing to a number of factors. [4] identified some of these factors as: low yield, inconsistent production patterns, disease incidence, pest attack and use of simple farm tools. In addition, [5] identified ageing cocoa farms as one of the factors responsible for the decline in cocoa production in south western Nigeria. He observed that many farms were over 40 years old and such farms constitute as much as $60 \%$ of the cocoa farms in Nigeria. However, in a study conducted by [6], it was found that most cocoa farms in Ondo and Osun states are very old with low productivity. All these resources are bound to result in an inefficient use of resources.

[7] characterize resources into variable and fixed resources. Variable resources include labour, seeds and fertilizers, which are normally used up in one production process. Fixed resources are more durable resources, which contribute to the production process over several production periods. They include land, machinery, farm building etc. [8] stated that production economics is concerned with optimisation and optimisation implies efficiency. Efficiency measurement is important because it leads to a substantial resource savings [9]. Efficiency measurement is important for three main reasons: Firstly, it is a success indicator and performance measure by which production units are evaluated. Secondly, the exploring of hypothesis concerning the sources of efficiency differential can only be possible by measuring efficiency and separating its effects from the effects of the production environment. Thirdly, identification of sources of inefficiency is important to the institution of public and private policies designed to improve performance [10]. One of the strategies for increasing agricultural production is a combination of measures designed to increase the level of farm resources as well as make efficient use of the resources already committed to the farm sector. [11], observed that technical inefficiency arises when less than maximum output is obtained from a given bundle of factors while allocative inefficiency arises when factors are not used in proportions, which do not lead to profit maximization. Efficient use and allocation of resources imply that a redistribution or re-allocation of resources achieves optimal level of production. Econo mic efficiency combines both technical and allocative efficiencies. It occurs when a firm chooses resources and enterprises in such a way as to attain economic optimum. The analys is 
of efficiency is generally associated with the possibility of farms producing a certain optimal level of output from a given bundle of resources or certain level of output at least cost.

Production function analysis for estimation of efficiency of resource use in crop production systems and determination of the optimal resource allocation for adjustment in resource allocation has been employed in some studies $[12,13]$. They reported that there was inefficiency in the use of resources. Hence, adjustments in resource allocation for economic optimum might be required to meet the needed percentage change based on the equality of marginal value products and marginal factor costs of inputs. One way of increasing production by the small farmers is to efficiently use all the resources available in the production process. [14] indicated that the most productive and efficiently used inputs are labour, seeds and farm equipment. Land as a resource is efficiently used through shifting cultivation practices and other cropping systems [15], but the full potentials of land, capital and labour resources are yet to be efficiently husbanded for optimum production. There is need to develop a sound knowledge of the current situation as regard cocoa farmers in Nigeria, and most especially as regards to the utilization of the available resources to them. This study is therefore designed to determine the efficiency of resource-use among cocoa farmers in the study area.

\section{Methodology}

The data used for the study were collected by administering a well-designed questionnaire to cocoa farmers in the study area (Ondo State of Nigeria). Simple random sampling was used in the selection of respondents from the study area. Ninety (90) cocoa farmers were interviewed with the use of structured questionnaire. The questionnaire sought general information on farmer's farm size, input used, cost of production, revenue generated and so on. The analytical tools used included descriptive statistics, farm budgetary technique and production function analysis. Budgetary technique was used to estimate the cost and returns on cocoa production.

The following arithmetical relations are used in the study.

Total Cost $($ TC) $=$ Total Fixed Cost $($ TFC $)+$ Total Variable Cost (TVC)

Gross Revenue $($ GR) $=$ Total Farm Output (TFO) $x$ Unit Price (UP)

Gross Margin $(\mathrm{GM})=\mathrm{GR}-\mathrm{TVC}$

Net Farm Income (NFI) $=$ GM - TFC

Following [16], to derive marginal product of cocoa production inputs for a production season, a cocoa

production function was estimated using ordinary least squares. The implic it form of the model is presented thus

$\mathrm{Y}=\mathrm{f}\left(\mathrm{X}_{1}, \mathrm{X}_{2}, \mathrm{X}_{3}, \mathrm{X}_{4}, \mathrm{X}_{5}, \mathrm{U}\right)$

Where $\mathrm{Y}=$ Gross income $(\mathrm{A})$;

$\mathrm{X}_{1}=$ Cost of Che micals $(\mathrm{N})$;

$\mathrm{X}_{2}=$ Cost of labour $(\mathrm{N})$;

$\mathrm{X}_{3}=$ Cost of nylon $(\mathrm{N})$;

$\mathrm{X}_{4}=$ Cost of cutlass $(\mathrm{N})$;

$\mathrm{X}_{5}=$ Cost of sprayer $(\mathrm{N})$;

$\mathrm{U}=$ Random error term.
There was no assumption as to the form that gives the best fit. Linear, semi-log, double-log and exponential forms were fitted and the best was chosen based on established statistical, economical and econometric criteria.

The Marginal Value Product (MVP) of each resource used in the production process was measured using the formulae

MVPxi = biXi [16]

Where MVPxi = MVP of resource xi $(i=1,2,3,4,5)$

$\mathrm{bi}=$ regression coefficient of resource $\mathrm{xi}$

$\mathrm{Xi}=$ unit price of resource $\mathrm{xi}$

Economic theory states that a firm maximizes its profit with respect to input used if the ratio of its MVP to its Marginal Factor Cost is one. A ratio greater than unity shows under-utilisation of that resource and profit would be increased by increasing the quantity used of that input. A ratio lesser than unity indicates the over-utilisation of input and decreasing the use of that input will increase the level of profit. Hence,

(1) if MVPxi = MFCxi, farmers are efficient in the use of $x i$

(2) if MVPxi > MFCxi resource xi is under-utilised

(3) if MVPxi < MFCxi, resource xi is over-utilised.

However, scenarios 2 and 3 indicate inefficiency.

\section{Results and Discussion}

\subsection{Cost and Returns Analysis to Cocoa Production}

Table 1 shows that while variable cost per farmer was $\mathrm{N} 109,491$, the average fixed cost and average gross revenue were $\mathrm{N} 11,183$ and $\mathrm{N} 722,827$ respectively. The gross margin and net farm income per farmer were N613,335 and N602,152 respectively. Thus cocoa farmers in the study area are operating profitably. Table 1 also shows that while total variable cost accounts for $90.7 \%$ of the total cost of production, the total fixed cost was $9.3 \%$

Table 1.Cost and returns of cocoa farmers
\begin{tabular}{|c|c|c|}
\hline No & Item & Cost $(\mathbf{A})$ \\
\hline 1 & Total Variable Cost & $9,854,230$ \\
\hline 2 & Average Variable Cost per farmer & 109,491 \\
\hline 3 & Total Fixed Cost & $1,006,520$ \\
\hline 4 & Average Fixed Cost per farmer & 11183 \\
\hline 5 & Gross Revenue & $65,054,400$ \\
\hline 6 & Gross Revenue per farmer & 722827 \\
\hline 7 & Gross Margin & $55,200,170$ \\
\hline 8 & Gross Margin per farmer & 613,335 \\
\hline 9 & Net Farm Income & $54,193,650$ \\
\hline 10 & Net Farm Income per farmer & 602152 \\
\hline
\end{tabular}

Source: Survey data, 2010.

\subsection{Farm Production Function of Cocoa Farmers}

The double-log function was function chosen as the lead equation based on the significance of the individual coefficients, signs of coefficients (conformity with $a$ priori expectation), the magnitude of the F-value and the magnitude of the coefficients of multiple determination, $\mathrm{R}^{2}$

The selected lead equation is presented below: 
$L_{n} Y=b_{o}+L_{n} b_{1} X_{1}+L_{n} b_{2} X_{2}-L_{n} b_{3} X_{3}+L_{n} b_{3} X_{3}+$ $\mathrm{L}_{\mathrm{n}} \mathrm{b}_{4} \mathrm{X}_{4}-\mathrm{L}_{\mathrm{n}} \mathrm{b}_{5} \mathrm{X}_{5}$ $2.021+0.785 \mathrm{X}_{1}+0.571 \mathrm{X}_{2}+0.282 \mathrm{X}_{3}+$ $0.316 \mathrm{X}_{4}+0.422 \mathrm{X}_{5}$

$$
(4.141) \quad(2.516)
$$

$$
\text { (3.103) (3.115) }
$$$$
\mathrm{R}^{2}=0.607, \text { F-value }=21.855, \mathrm{D}-\mathrm{W}=2.311 \text {. }
$$

The $\mathrm{R}^{2}$ of 0.607 connotes that $60.7 \%$ of the variations in farmer's gross income are accounted for by the regressors (explanatory variables). The F-value showed that the overall equation is significant at the $1 \%$ level. The coefficients of the cost of chemicals $\left(X_{1}\right)$, labour $\left(X_{2}\right)$, nylon $\left(\mathrm{X}_{3}\right)$ and cutlass $\left(\mathrm{X}_{4}\right)$ and sprayer $\left(\mathrm{X}_{5}\right)$ are all significant at $1 \%$ level showing that these costs items are critical in cocoa production. The positive sign of variables $\mathrm{X}_{1}, \mathrm{X}_{2}$ and $\mathrm{X}_{4}$ shows that as expenditure on these cost items increases, revenue also increases, while the negative sign on variables $X_{3}$ and $X_{5}$ shows that as the expenditure on these variables increases, revenue decreases.

The elasticity of production (derived directly from the coefficient of the regression equation) with respect to the cost of chemicals, cost of labour, cost of nylon, cost of cutlass and cost of sprayer were $78.5 \%, 57.1 \%, 28.2 \%$, $31.6 \%$ and $42.2 \%$ respectively. This however means that there is an increase of $78.5 \%, 57.1 \%$ and $31.6 \%$ in the gross income of the farmers with $100 \%$ increase in the cost of chemicals, cost of labour and cost of cutlass while there is a decrease of $28.2 \%$ and $42.2 \%$ in the gross income of the farmer with $100 \%$ increase in the cost of nylon and sprayer respectively.

\subsection{Marginal Value Product for Cocoa Farmers}

It could be observed on Table 2 that the marginal value product (MVP) for chemical was N197.50. This implies that if other inputs were held constant (at their geometric means), increasing fungicide by $1 \%$ would increase the Total Value Product (TVP) by N197.50. The MVP for chemical is greater than MFC, thus making the MVP/MFC greater than one. This simply implies that chemical were being used below their economic optimum level. Cocoa farmers could increase their profit by increasing their chemical utilisation. The table further shows that the ratio of MVP to MFC for costs of labour, nylon, cutlass and sprayer were greater than unity showing that these inputs were being used below their economic optimum levels. Therefore, cocoa farmers in the study area could only increase their profits by increasing the quantity of these inputs. Hence, cocoa farmers in the study area are inefficient in the use of these inputs.

Table 2. Marginal value products for cocoa farmers

\begin{tabular}{|c|c|c|c|}
\hline Table 2. Marginal value products for cocoa farmers \\
\hline Input & MVP & MFC & MVP/MFC \\
\hline Chemicals & 197.50 & 0.79 & 250.00 \\
\hline Labour & 228.00 & 0.57 & 400.00 \\
\hline Nylon & -84.60 & -0.28 & 23.86 \\
\hline Cutlass & 160.00 & 0.32 & 500.00 \\
\hline Sprayer & -1260.00 & -0.42 & 3000.00 \\
\hline
\end{tabular}

Source: Field survey, 2010

\section{Conclusion and Recommendation}

The proportion of the total cost of production to the gross income was $16.70 \%$, hence the average net farm income was N602,152.00 showing that cocoa production is profitable in the study area. The elasticity of production for cost of chemicals, cost of labour, cost of nylon, cost of cutlass and cost of sprayer were $78.5 \%, 57.1 \%, 28.2 \%$, $31.6 \%$ and $42.2 \%$ respectively ind icating that it is the cost of fungicide that is most responsive. The ratio of the MVP to MFC for chemicals, labour, nylon, cutlass and sprayer is greater than unity, hence, these inputs were underutilized and thus the inputs were in-efficiently utlilised by farmers in the study area.

It is therefore recommended that for these inputs to be efficiently utilized, the quantity of the inputs should be increased by cocoa farmers in the study area.

\section{References}

[1] Opeke, L.K. Tropical Tree Crops. Ibadan: Spectrum Books Ltd, pp.1-15, pp.108-120. 1982.

[2] Ayorinde, J.A. Historical Notes on the Introduction and Development of Cocoa Industry in Nigerian. Agricultural Joumal, 3: 18-23, 1966.

[3] Adegbola, M.O.K. and Abe, J.O. Cocoa Development Programme, Nigeria. Research Bulletin No 9. Cocoa Research Institute of Nigeria Printing Unit, pp. 3-5. 1983.

[4] Oduwole, O.O. Adoption of Improved Agronomic Practices by Cocoa Famers in Nigeria: A Multivariate Tobit Analysis. Ph.D. Thesis (Unpublished), Akure: Federal University of Technology, Nigeria. 2004.

[5] Villalobos, V.M. Advances in Tissue Culture Methods Applïed to Coffee and Cocoa Plant Biotechnology for Developing Countries. United Kingdom: CTA/ FAO ChaycePublication Services, 1989.

[6] Daramola, A.G., Fuwape, J.A., Ofuya, T.I., Okunlola, J.O., Ajibefun, I.A., Okuku, I.E., Oke, D.O., Aladesaiye, E., Badaru, K.B and Olaiya, A.O. Evaluation of Sustainable Options for Rehabilitation for Small Holder Nigerian Farmers. Sustainable and Competitive Cocoa System in Africa. Economics. 16: 47-53. 2003.

[7] Olukosi, J.O. and Erhabor, P.O. Introduction to Farm Management Economics: Principles and Applications. Zaria: AGITAB Publishers. 1980.

[8] Baumol, C.F. Principles of Micro Economics. $3^{\text {rd }}$ Edition, Englewood Cliffs, NJPrentice Hall. 1977.

[9] Bravo-Ureta, B.E.and Rieger, L. Dairy Farm Efficiency measurement using Stochastic Frontier and Neoclassic Duality. American Journal of Agricult ural Economics, 73: 421 -428. 1991.

[10] Ogunjobi, O.P. Efficiency of Smallholder Cocoa Farmers in Ondo State: A Stochastic Frontier Analysis. M. Sc Thesis, Unpublished, Federal University of Technology, Akure. 1999.

[11] Farrel, J.M. The Measurement of Productive Efficiency. Journal of Royal Statistic, 120(3): 253-290. 1957.

[12] Rahman, S.A. and Lawal, A.B. Economic Analysis of MaizeBased Cropping Systems in Giwa Local Government Area of Kaduna State, Nigeria. An International J. of Agric. Sci., Sci., Environment and Technology. 3(2): 139-148, 2003.

[13] Iheanacho, A.C., Olukosi, J.O. and Ogunbile, A.O. Economic Efficiency of Resource Use in Millet-Based Cropping Systems in Borno State of Nigeria, Nigerian J. of Tropical Agric. 2: 33-42. 2000.

[14] Olaide, S.O. Characteristics, Problems and Significance of Farmers. In: SO Olaide, Eweka Bello (Eds.): Nigeria Small Farmers. Problems and Prospects in Integrated Rural Development. Published by centre for Agricultural, Rural and Development (CARO), University of Ibadan, Nigeria. 1980.

[15] Okigbo, B.N. Cropping Systems and Related Research in Africa. AAASA. Anniversary Series. 1978.

[16] Dikwal, M.M., Malomo, S.S., Okeke, K.I. and Nyam, T. Resource Use Efficiency in Small scale Commercial Broiler Chicken Enterprise: A case study of Jos South Local Government Area, Plateau State, Nigeria. Proceedings of $20^{\text {th }}$ Annual Conference of Farm Management Association of Nigeria (FAMAN) held between 18-21 September, 2006. pp. 59-62. 2006. 